\title{
Business Valuation: Modelling Forecasting Hurdle Rate
}

\author{
Dr. V.K. Nangia \\ Professor\& Head, Department of Management Studies \\ Indian Institute of Technology Roorkee, Roorkee 247667, Uttarakhand, India \\ E-mail: nangvfdm@iitr.ernet.in \\ Dr. Rajat Agrawal \\ Assistant Professor, Department of Management Studies \\ Indian Institute of Technology Roorkee, Roorkee 247667, Uttarakhand, India \\ E-mail: rajatfdm@iitr.ernet.in \\ K. Srinivasa Reddy (Corresponding Author) \\ Doctoral Student (Ph.D), Department of Management Studies \\ Indian Institute of Technology Roorkee, Roorkee 247667, Uttarakhand, India \\ E-mail: srinuddm@iitr.ernet.in
}

Received: June 25, 2011 Accepted: November 18, 2011 Published: December 1, 2011

doi:10.5296/ajfa.v3i1.724 URL: http://dx.doi.org/10.5296/ajfa.v3i1.724

\begin{abstract}
Consolidation, Combination and Diversification (CCD’s) in the emerging globalized market leads to competition and escalating the monopoly power. Given the increasing liberalization of rules, regulations and law, a number of firms are going beyond national borders and making deals triumphant. We suggest an innovative firm valuation model for M\&A in the area of Corporate Finance that is NRR Approach 1.0. The methodology is divided into five phases, modeling forecasting hurdle rate, finding sales growth rate, computation of free cash flows \& estimation of future free cash flows and finally determination of firm value under NRR approach. The findings suggest that NRR approach considers various imperative factors while valuing target firms for the benefit of shareholders. The value of study could be credited by NRR Approach 1.0. and this is the first of its kind model considers political, transfer and commercial risk factors while estimating hurdle rate. Hence, approach is the first version of development thought and has limited scope to validate in other industries. We
\end{abstract}




\section{Macrothink}

Asian Journal of Finance \& Accounting ISSN 1946-052X 2011, Vol. 3, No. 1: E6

believe that NRR model shall be of great help to M\&A advisory firms and investment bankers while negotiating deal value in acquisition process. This would be help in exploring new dimensions of judgment and approach for academia as well as for the benefit of target firm shareholders in corporate arena.

Keywords: Business valuation, Mergers, Acquisitions, Hotel \& tourism, Forecasting

JEL Classification: G30; G31; G34 


\section{Introduction}

There is no more dramatic activity in corporate finance than the acquisition of one firm by another or merger of two firms. In investment perspective, a firm should estimate future cash flow generating capacity of target firm and determination of enterprise value to be acquired for the benefit of shareholders (Pandey, 2009). Mergers and acquisitions (M\&A) is a response to new technologies or market conditions which require a strategic change in company's direction or use of resources (Ray, 2010).

M\&A and restructuring are a big part of the corporate finance world. The key principle behind buying a company is to create shareholder value over and above that of the sum of two companies (Pandey, 2009). The recent M\&A boom in India has been comprised exclusively of friendly deals. Since economic liberalization in 1991, India has experienced only a handful of hostile takeover attempts. Over the past few years, M\&A transactions has grown-up greatly, in particular Indian deals have risen from \$4.9 billion in 2006 to \$6.7 billion in 2009 (Grant Thornton - Dealtracker, 2008).

Economic analysis, business professionals and research evidence indicate that corporate restructuring, mergers, acquisitions, takeovers, and leveraged buyouts are playing an important role in helping the economy adjust to major competitive changes.

- Jensen, M.C. (Ross et al., 2005, p. 808)

Hence, we focus on valuation part while acquiring or buying a target firm as a whole. Business valuations are performed and conventionally categorised into three groups (West \& Jeffrey, 1999). These are transaction based approach, tax-based approach and litigation based approach. First, the transaction based approach is found in mergers, acquisitions, divestitures, employee stock option plan (ESOPs), buy-sell agreements, leveraged buyouts, fairness \& solvency options and debt/equity financing (Fernandez, 2002; 2007a \& 2007b). Second, tax-based valuations occasionally occurred in the case of gift \& estate taxes, estate planning, charitable contributions, creation of family limited partnerships (FLPs) and granting of stock options. Finally, litigation-driven valuations are most common in divorce of partnership, bankruptcy, shareholder actions, breach of contract and a variety of break-up transactions The present study of 'Firm valuation and cash flows' is fall under the method of 'transaction based approach'.

The present conceptual study suggests a new valuation model by undertaking two case examples in the Indian tourism \& hospitality industry. The remaining study is organized as follows: section 2 describes Indian tourism \& hospitality industry, section 3 presents company profiles; section 4 construe the literature review, section 5 state the valuation method and results discussed in section 6. Finally, conclusions presented in section 7.

\section{Indian Tourism \& Hospitality Industry}

Indian culture replicates by the philosophy of "Atithi Devo Bhava", mean that "the guest is God" in Sanskrit language. Tourism has been a major social phenomenon of societies all over the world. It is driven by the natural urge of every human being for new experiences, the 
desire to be educated and entertained. The basic human craving for new experience and knowledge has become stronger, as communication barriers are getting overcome by technological advances. We describe that the progress in air transport and development of tourist facilities has encouraged entrepreneurs to venture beyond cross-borders. Hence, tourism is considered to be a tool of economic development and employment generation for developing nations. It is one of the largest focused industries in service sector globally, in terms of revenue and foreign exchange earnings. Tourism plays an important and effective role in achieving the growth and sustainable development of a nation.

After 1990's liberalization policy, India's performance in tourism sector has been quite impressive. During 2002-09, country witnessed an impressive growth in foreign tourist arrivals (FTAs) from 2.38 million to 5.11 million. Due to the global slowdown \& financial crisis, terrorist activities, H1N1 influenza pandemic, etc., the growth rate in FTAs in 2009 fell by 3.3 per cent. Foreign exchange earnings (FEEs) from tourism increased from \$ 3.2 billion in 2002 to $\$ 11.75$ billion in 2009 (Ministry of Tourism, Government of India).

The recently held Common Wealth Games (CWG) - 2010 at New Delhi, pushed Indian tourism and hospitality sector to grasp budding opportunities in the welcoming world. It is expected that the industry will record strong growth over the next years, resulting from the growing international tourist arrivals, and other developments in heritage and culture occasions. Government also seems to keen on growth of tourism sector, which was apparent from its policy decision such as recent delinking of hotels from the high risk category of real estate business, so that the sector can get passable loans at lower interest ([India Infoline data warehouse]); and permitting the industry to raise external commercial borrowings (ECBs).

The demand for travel and tourism in India is expected to grow by 8.2 per cent between 2010 and 2019 and would be placing India at the third position in the world. According to a report by RNCOS, medical tourism will grow at a compound annual growth rate of over 27 per cent during 2009-12 to generate revenues \$2.4billion by 2012. The number of medical tourists is anticipated to grow at a CAGR of over 19 per cent to reach 1.1 million by 2012. Further, the report adds that India's share in the global medical tourism industry will climb 2.4 per cent by the end of 2012. According to Federation of Hotel \& Restaurant Associations of India (FHRAI), India currently has over two lakh hotel rooms spread across hotel categories \& guest-houses and is facing a shortfall of over one lakh rooms. The members include hotels and restaurants are depicted in Table 1 below. 
Table 1. Break-up of FHRAI Members as on Aug 23, 2010

\begin{tabular}{|c|c|c|c|c|c|c|c|c|c|c|}
\hline \multirow{2}{*}{ Category } & \multicolumn{2}{|c|}{ EAST } & \multicolumn{2}{|c|}{ NORTH } & \multicolumn{2}{|c|}{ SOUTH } & \multicolumn{2}{|c|}{ WEST } & \multicolumn{2}{|c|}{ TOTAL } \\
\hline & Hotels & Rooms & Hotels & Rooms & Hotels & Rooms & Hotels & Rooms & Hotels & Rooms \\
\hline 5 Stat Deluxe & 9 & 1365 & 36 & 8492 & 23 & 4088 & 37 & 9230 & 105 & 23175 \\
\hline 5 Star & 3 & 322 & 34 & 3971 & 30 & 3871 & 38 & 4213 & 105 & 12377 \\
\hline 4 Star & 11 & 784 & 44 & 3665 & 45 & 4099 & 35 & 3075 & 135 & 11623 \\
\hline 3 Star & 32 & 1566 & 88 & 3910 & 186 & 10921 & 121 & 7091 & 427 & 23488 \\
\hline 2 Star & 11 & 340 & 20 & 743 & 32 & 1363 & 37 & 1495 & 100 & 3941 \\
\hline 1 Star & 1 & 42 & 5 & 78 & 6 & 225 & 6 & 233 & 18 & 578 \\
\hline Heritage & & & 29 & 1085 & 8 & 340 & 8 & 318 & 45 & 1743 \\
\hline Un-Classified & 198 & 7471 & 442 & 16514 & 332 & 16898 & 393 & 14978 & 1365 & 55861 \\
\hline Restaurants & 135 & 12483 & 517 & 44134 & 252 & 23422 & 229 & 150620 & 1133 & 230659 \\
\hline Associates & 17 & & 60 & & 41 & & 30 & & 148 & \\
\hline Organizations & 1 & & 1 & & 1 & & 1 & & 4 & \\
\hline Total & 418 & & 1276 & & 956 & & 935 & & 3585 & \\
\hline
\end{tabular}

\section{Case Illustration Approach}

To achieve the objective of study, we undertake two case examples while validating new valuation model, namely The Oberoi hotels (formerly EIH Ltd) and The Leela hotels (formerly Hotel Leelaventure Ltd).

\subsection{The Oberoi Hotels (EIH Ltd)}

EIH Ltd is the flagship company of Oberoi group and the largest chain of hotels in India. It is in the business of luxury hotels, restaurant, management contracts and travel and tours. The Oberoi group, founded in 1934, employs more than 12000 people worldwide and operates 28 hotels \& three cruisers in five countries under the luxury 'Oberoi' and five-star 'Trident' brands. Apart from the core business, it is engaged in flight catering, airport restaurants, travel and tour services, car rentals, project management and corporate air charters. Trident hotels are five-star hotels that have established as a reputation for excellence and are acknowledged for offering quality and value. These hotels combine state of the art facilities with dependable service in a caring environment, presenting the ideal choice for business and leisure travelers, presently there are nine Trident hotels in India.

Mr. P.R.S. Oberoi is the Chairman and Chief Executive Officer of EIH Limited (The Oberoi Group). He is also the Chairman of Oberoi Hotels Private Limited, the major shareholder of EIH Limited, known as 'Biki'. Mr. Oberoi is the son of late Rai Bahadur M.S. Oberoi, the founder of The Oberoi Group. In January 2008, Oberoi awarded as 'Padma Vibhushan', India's second highest civilian honor, in recognition of his exceptional service (hospitality and tourism) to the country. In August 2010, Oberoi Hotels Pvt Ltd, Aravali Polymers LLP and Prithvi Raj Singh Oberoi sold 55.47 million shares, representing approximately 14.12 per cent of the share capital of the company to Reliance Industries Investment and Holding Pvt Ltd. 


\subsection{Hotel Leelaventure Ltd}

Hotel Leela Venture Ltd was incorporated in 1981. Leela entered into collaboration with Penta Hotels, UK to set up and operate 5-star hotels, which was subsequently transferred to Kempinski Hotels, a European chain of 5-star deluxe hotels, owned by Lufthansa, the German Airline. In 1986, the company set up their first 5-star deluxe hotel namely Leela Penta, in Mumbai. The hotel was renamed as Leela Kempinski in 1988, subsequent the change in their marketing and sales tie-up. Leela operates in both, the leisure and business sectors. The Leela palaces and resorts include a chain of five star luxury hotels and resorts. The company properties include The Leela Kempinski in Mumbai, The Leela Palace in Goa, The Leela Palace Kempinski in Bangalore and The Leela Kovalam in Kerala. The company became a popular name in the hospitality industry in India because of their high quality of service and customer relations. In a nut shell, Leela operates six hotels in various locations Mumbai, Bangalore, Goa, Kovalam, Udaipur and Gurgaon comprising 1523 guest rooms and 90 serviced apartments. Leela group is engaged in the business of ready-made garments and luxury hotels and resorts, founded in 1957 by Capt. C.P. Krishnan Nair. It was in 1957 when Capt. Nair, after completing his stretch in the army, set up a small industrial unit in suburban Mumbai. Inspired by the handloom weaving industry in Cannanore, Kerala was India's first and only lace manufacturing plant 'Leela Scottish Lace Ltd'.

\section{Review of Literature}

The review of literature includes associated studies on business valuation, merger valuation, factors effecting on valuation and estimation of free cash flows; however these are organized in sequence to support the study. Most of the academicians and researchers have studied comparison of DCF, DDM and RI methods (Plenborg, 2002; Bailey et al., 2008; Velez-Pareja \& Tham, 2010), effect of earnings management on firm value (Chaney \& Lewis, 1995), cultural distance and firm valuation (Antia et al., 2007), Tobin's Q as an estimate of market valuation (Yermack, 1996), predicting future cash flows (Misund et al. 2008) and impact of mergers on firm value (Ma et al., 2010). Antia et al (2007) examines the value impact of cultural differences that exist between foreign subsidiaries and headquarters of U.S. Multinational corporations (MNCs). They found negative relationship between cultural distance and firm valuation. Most of the individual cultural attributes that make up the index have a negative effect on firm valuation. The findings are consistent with the notion that cultural differences decrease firm value by imposing a barrier to the exploitation of internalization advantages.

Bai et al (2004) investigate empirically the relationship between governance mechanisms and the market valuation of publicly listed firms in China. They construct measures of corporate governance and market valuation for all publicly listed firms on two stock markets in China from the firm's annual reports during 1999-2001. Their results support several theoretical predictions that both high concentration of non-controlling shareholding and issuing shares to foreign investors have positive effects on market valuation. Fernandez (2007b) summarizes compendium of ten methods including: free cash flow; equity cash flow; capital cash flow; adjusted present value; business's risk adjusted free cash flow and equity cash flow; risk-free 
rate-adjusted free cash flow and equity cash flow; economic profit; and economic value added. These ten methods always give the same value. Finally, he concludes by analyzing ten methods of company valuation using discounted cash flows and nine different theories about the VTS.

Lin \& Su (2008) investigate the relationship between industrial diversification and firm valuation for a sample of 816 publicly listed firms in China. They found that when the decision to diversify is modelled as an endogenous choice based on firm characteristics, multi-segment firms have significantly higher Tobin's q than single-segment firms, even after controlling for factors such as ownership structure, ownership concentration, and growth opportunities. Misund et al (2008) suggest that contemporaneous earnings are more useful than current operating cash flow in predicting future cash flows and more relevant for company valuation. They found that the value relevance of cash flows actually decreased in the recent oil industry upheaval.

Bailey et al (2008) states that residual income model (RIM) provides better estimates of firm value than two other commonly used DCF and DDM models. Further, there is less need to forecast returns as far into the future and with this model, a terminal value based upon a constant future return (or relatively low growth rates) can be used. On the other hand, Plenborg (2002) compares DCF and RIM. The two valuation approaches are compared on the basis of analytical attractiveness. RIM yields more accurate firm value estimates, while in others the DCF approach yields more accurate estimates. Finally, the framework for forecasting is often based on accrual accounting and the budget control is generally based on accounting numbers rather than cash flow numbers. Interestingly, Velez-Pareja \& Tham (2010) compute cash flows namely, cash flow to debt (CFD), cash flow to equity (CFE), capital cash flow (CCF), free cash flow (FCF) and tax savings (TS). They use direct and indirect methods to derive the relevant cash flow profiles for the different stakeholders. These cash flows are the basis for the valuation of a firm or project.

Other studies include, Wilcox et al (2001) uses event analysis to examine 44 M\&A events involving 89 partners in the telecommunications industry. Their study formulates and tests hypotheses relating the impact of near and far diversification, and the size of the firm, on market valuation. Their results suggest that while overall these events weight positively on market value, M\&A involving near-diversification and larger firms tend to experience greater valuation effects. Yermack (1996) evidences the consistent with theories that small boards of directors are more effective, using Tobin's Q as an approximation of market valuation. The study found an inverse association between board size and firm value in a sample of 452 large U.S. industrial corporations during 1984-91. The results are robust to numerous controls for company size, industry membership, inside stock ownership, growth opportunities, and alternative corporate governance structures.

In summary of the above literature, there is no method or model or theory that undertakes macro and political factors while determining firm value, particularly in M\&A practice. On the other hand, time has been changed from home-made to local market, public to private, domestic to international and multinational to globalization, since the modern business needs 
new financial models, theories, methods, approaches and innovations for the next generation corporate finance to protect the stakeholders believe and trust. Consequently, it gives us an opportunity to introduce new model in valuation, particularly our study is aimed to suggest a method for hotels and resorts with the help of two case examples.

\section{Research Method}

\subsection{Objective of the study}

M\&A have become a popular vehicle for cash-full and rising companies to rapidly access new markets, assets and capabilities. The motive behind our study is to develop new financing models in the upcoming area of M\&A advisory. Exclusively, it suggests a new valuation cum forecasting model to build theories, concepts and strategies in the emerging field of corporate finance.

\subsection{Data collection and analysis}

We have collected data from recognized sources and used as the background of study, literature review, two case examples (EIH and Leela) and other imperative factors, which is required for modelling a new valuation model. The main profile of case examples extracted from leading business news papers, referred publications and company's official sites, for example India Infoline data warehouse. The data including market capitalization, market share and financial statements of both companies and industry information were absorbed from CMIE Prowess database, FHRAI and Ministry of Tourism. The financial data of two case examples has been analyzed under NRR approach, expressed in methodology section below.

\subsection{Valuation methodology}

Growing importance of 'Business Valuation' as a specialized area in corporate finance, we suggest a new method, namely the process which is modeling forecasting hurdle rate (FHR), modified net asset valuation model, computation of goodwill and firm valuation. First, we compute FHR, then statement of free cash flows (Fernandez, 2003; 2007b), estimating future sales growth rate, there after future free cash flows and finally determination of enterprise value $\left(\mathrm{V}_{\mathrm{C}}\right)$. The NRR methodology flow chart is presented in Figure 1 below. However, this model is first version and final edition of NRR approach will be developed accordingly. 


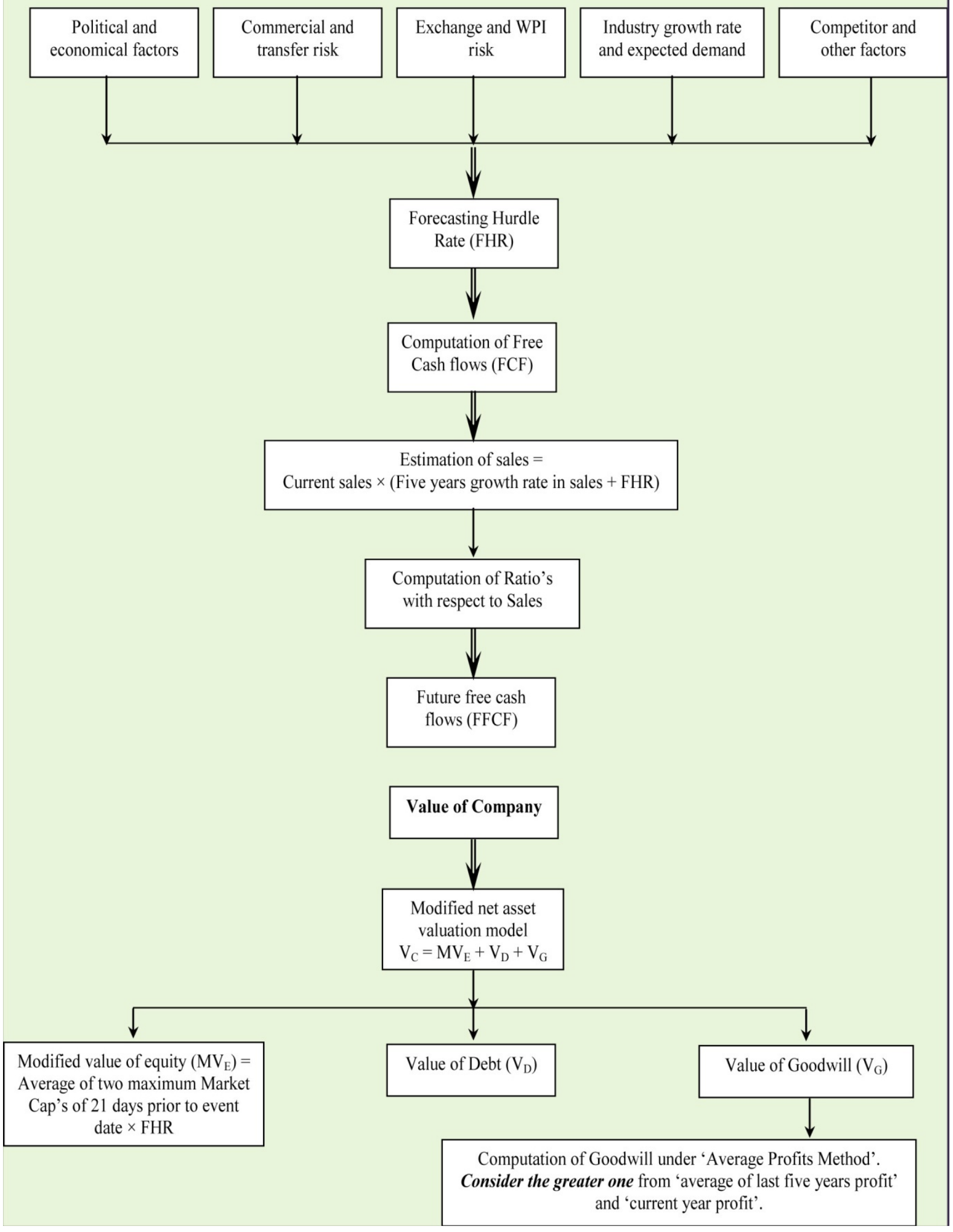

Figure 1. Firm Valuation and Cash flows - NRR approach 


\subsubsection{Forecasting hurdle rate (FHR)}

Forecasting is the process of estimation in unknown situations from the historical data for the purpose of future decision making. There are various models suggested by economics and finance scholars. Here, we develop a model that named as "forecasting hurdle rate" by using various economic, political, industry, financial and production factors. The main objective of model is to find out the relative rate for estimating sales or revenues. The acquirer may consider various above said factors while valuing the business or company.

Forecasting Hurdle Rate $(\mathrm{FHR})=$

$$
\frac{\beta 1 \mathrm{DNSGR}+\beta 2 \mathrm{GHGR}+[\mathrm{MS} \times \mathrm{GRAT}]+[\mathrm{MS} \times \mathrm{DDT}]-[\mathrm{PCMS} \times \mathrm{GRAT}]-[\mathrm{PCMS} \times \mathrm{DDT}]}{\log \mathrm{WPI} . \mathrm{GR}+\log \mathrm{Cm} . \mathrm{R}+\log \mathrm{EX} . \mathrm{R}+\log \mathrm{PRST}+\log \mathrm{TR}} \times 100
$$

Where,

DNSGR is domestic net sales growth rate, GHGR is global hospitality growth rate, $M S$ is market share of select case, GRAT is growth rate in arrival of tourists, DDT is domestic demand in tourism, PCMS is prime competitor market share, WPI.GR is whole sale price index of food articles (growth rate against five preceding years), Cm.R is commercial risk, $E X . R$ is exchange risk (Rupee vs. US\$), PRST is political risk for special transactions, TR is transfer risk and $\log$ is logarithm.

\subsubsection{Estimating future free cash flows (FFCF)}

Before estimating FFCF, first we compute the statement of free cash flows on the basis of last year (2009-10) financial information. The FCFs are the fundamental base to project the FFCF (Damodaran, 1996) with respect to cash flow productive rate. FCF is computed under the regulations of Indian accounting practices. After, computing various ratios with respect to sales and assets, the same percentage has undertaken to estimate future free cash flows. This is an abridged formulae and stating that consider while estimating firm value under DCF method. Since, it has been suggested for further research to the next version of NRR.

$$
\text { Estimated sales }=\frac{\text { Current sales } \times(\text { Estimated sales growth rate })}{100}+\text { Current sales }
$$

$$
\text { (Estimated sales growth rate } \left.=\text { five years average sales growth rate }{ }^{1}+F_{H R}\right)
$$

\subsubsection{Modified net asset valuation model (MNAVM-NRR approach 1.0.)}

Wholly, we compute total value of company or business by using 'net asset valuation model (NAVM)'. This model primarily used to compute the total value of company in terms of equity and debt. It would be a considerable method for evaluating business value as a part of M\&A negotiations.

$$
\mathrm{V}_{\mathrm{C}}=\mathrm{MV}_{\mathrm{E}}+\mathrm{V}_{\mathrm{D}}+\mathrm{V}_{\mathrm{G}}
$$

\footnotetext{
1 Average growth rate for sales computed on year-on-year (yoy) basis and we ignore the current year sales growth rate, i.e. 2009-10
} 


\section{Macrothink}

Where, $\quad \mathrm{V}_{\mathrm{C}}=$ total value of the company; $\mathrm{MV}_{\mathrm{E}}=$ modified value of equity ${ }^{2}$;

$$
\mathrm{V}_{\mathrm{D}}=\text { value of debt; } \mathrm{V}_{\mathrm{G}}=\text { value of goodwill }{ }^{3}
$$

\subsubsection{Computation of Goodwill}

Goodwill factor has not been considered as a separate element in most of the methods (Plenborg, 2002; Bailey et al., 2008; Velez-Pareja \& Tham, 2010), though NRR considers goodwill as an elective in service industries. For example, hospitality is the leading service industry which creates name and fame of an organization in the mindset of visitors and society. Moreover in five star categories, room occupancy ratio is mainly depends upon the name of 'brand \& identity'. For justification and address this hospitality experience, we modified 'average profits method', while computing goodwill of an organization to consider different risks connected with business cycles, economic \& financial melt-down and sub-prime mortgage crisis. The consideration of goodwill is equal to 'average value of last five years profits or current year profit, whichever is higher.

\section{Results and Discussions}

To achieve the objective of study, we took net asset valuation model (NAVM) as the better comparison method. First, we present value of two selected companies under both methods in Table 2 below. NAVM comprises value of equity $\left(\mathrm{V}_{\mathrm{E}}\right)$ and value of debt $\left(\mathrm{V}_{\mathrm{D}}\right)$, where this study uses modified value of equity $\left(\mathrm{MV}_{\mathrm{E}}\right)$, value of debt $\left(\mathrm{V}_{\mathrm{D}}\right)$ and value of goodwill $\left(\mathrm{V}_{\mathrm{G}}\right)$ in NRR model. Therefore, we use FHR as the relative rate to maximise the value of equity in each case and computed value of goodwill by modifying 'average profits method'. Because the selected hospitality industry and its business mainly depend upon name \&fame, quality of service and development of tourism, etc. The study suggests valuation of hotels under NRR approach would be first bargaining price in M\&A process. 


\section{Mll Macrothink}

Asian Journal of Finance \& Accounting

ISSN 1946-052X

2011, Vol. 3, No. 1: E6

Table 2. Valuation of EIH Limited and Hotel Leela under NRR approach (in Rs. Crore)

\begin{tabular}{|c|c|c|c|c|c|c|}
\hline \multirow{8}{*}{ A } & \multicolumn{2}{|l|}{ Particulars } & \multicolumn{2}{|c|}{ EIH Limited } & \multicolumn{2}{|l|}{ Hotel Leela } \\
\hline & & & NRR approach & NAVM & NRR approach & NAVM \\
\hline & Modified value of equity & & Amount & Amount & Amount & Amount \\
\hline & & First Max & 5925.75 & & 2210.60 & \\
\hline & & Second Max & 5878.59 & & 2193.15 & \\
\hline & & Average Market Cap & 5902.17 & & 2201.88 & \\
\hline & & Forecasting hurdle rate (FHR) & 5.30 & & 4.92 & \\
\hline & & Modified value & 6214.99 & & 2310.10 & \\
\hline & $\begin{array}{l}\text { Value of equity on Sept 30, } \\
2010\end{array}$ & & & 5350.7 & & 2047.72 \\
\hline \multirow[t]{2}{*}{ B } & Value of Debt & & & & & \\
\hline & & Total borrowings & 1254.39 & 1254.39 & 2878.66 & 2878.66 \\
\hline \multirow[t]{4}{*}{ C } & Value of Goodwill & & & & & \\
\hline & & Five years average profit & 161.98 & & 107.78 & \\
\hline & & Current year profit & 57.23 & & 41.02 & \\
\hline & & Maximum value & 161.98 & - & 107.78 & - \\
\hline & Enterprise value $(\mathrm{A}+\mathrm{B}+\mathrm{C})$ & & 7631.36 & 6605.09 & 5296.54 & 4926.38 \\
\hline
\end{tabular}

Prior to detail discussion on value comparison between NRR and NAVM, describes that 'Average Market Cap' is the average of first max and second max (see Figure 1). Further, modified value can be defined as multiple of average market cap and FHR. Conversely, value of goodwill equals to maximum value of five years average profit and current year profit. For NRR approach, enterprise value of $\left(\mathrm{V}_{\mathrm{C}}\right)$ of EIH and Hotel Leela is Rs.7631.35 crore and Rs.5296.54 crore. Moreover from the acquirer's point of view, the value is opening bidding price, conversely from the target firm point of view, this is reasonable but not finally decided price. Debt/equity (D/E) ratio in both cases 0.89 and 1.41 respectively. The enterprise value of EIH and Leela under NRR approach is higher than NAVM, i.e. Rs.1026.27 crore and Rs.370.16 crore respectively. Therefore, shareholders of target firm would be getting a reward price of his own shares under this model. At the end of day, the existing shareholder should not feel sting.

Second face of the objective of study presents future free cash flows (FFCF) by estimating the sales growth rate and referred ratios with respect to sales. Figure 2 shows the FFCF of EIH and Hotel Leela for the period 2011 to 2020, which is estimated on the basis of '2010' financial data. The sales will grow by 14.07 per cent and 17.54 per cent in each case of EIH and Hotel Leela. According to future plans of two companies, the sales will grow additionally by 10 per cent from 2013 onwards. The compensation paid to employees is occupied as the most operating expenses in both cases and will increase additionally by 6 per cent annually as incremental cost. The remaining operating expenses as the same referred ratios in base year. 


\section{MInstitute Macrothink $^{m}$}

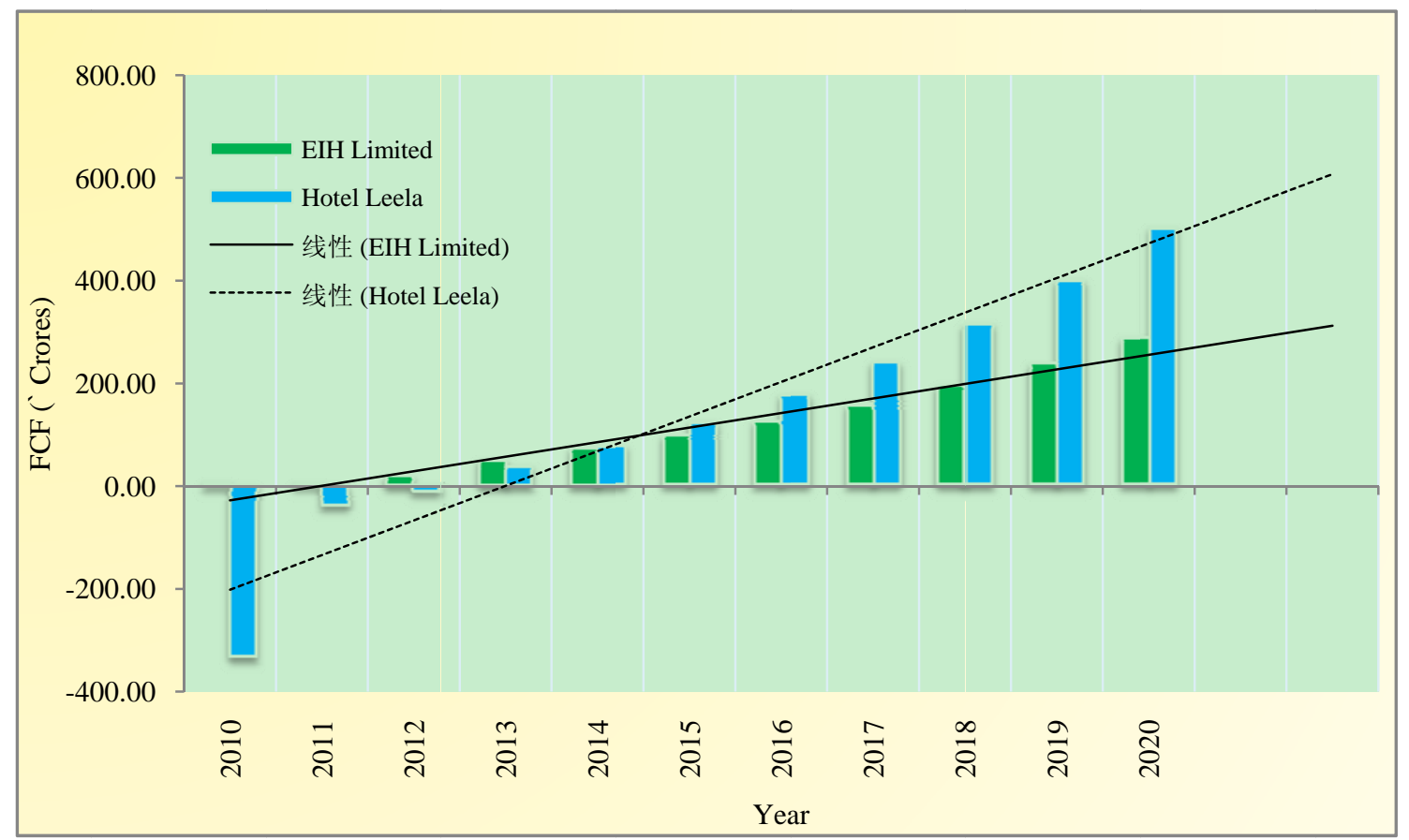

Figure 2. FFCF of EIH and Hotel Leela, 2010-2020

Further, we estimate the gross taxable amount against sales, on the other hand depreciation will amplify at 5 per cent annually in both cases. Capital expenditure will increase at 5 per cent in EIH Ltd and 40 per cent of 2010 capital expenditure in case of Hotel Leela. Finally, non-operating income will rise annually by 10 per cent in both cases. The balance sheet item 'increase/decrease in working capital' is computed with respect to sales in both cases and assume that no change till 2020. Further, study also computed selective ratios like EBIT, FCF, NOPLAT, operating expenses and compensation expenses with respect to sales for better inference and discussion. FFCF can be discounted for present value against discount rate, while estimating firm value under discounted cash flow (DCF) method.

\section{Conclusions}

Entrepreneurs have a curiosity knowing about the value of his company for future decision making purpose. The present study suggests a new firm valuation model in various phases/stages by considering diverse imperative factors in business environment. The study embarks on hospitality case examples (Oberoi and Leela) to validate the NRR approach in firm valuation under Indian accounting practices. NRR approach results show fresh business value by adding up value of goodwill and it is more than the NAVM. The study believes that the outcome value from the NRR approach is reasonable, fair and relative value, which may attract the shareholders of target firm. We hope this model may give much attention to investment bankers and M\&A advisory firms in modelling valuation for hotels \& resorts. Since the NRR approach seems to be an attractive under asset based models compare to income based models like RI to DCF (Plenborg, 2002; Velez-Pareja \& Tham, 2010). Exclusively, we acknowledge Fernandez (2002, 2003, 2007a \& 2007b) for his contribution on business valuation inspire us to develop this first version of NRR approach 1.0. 
However, study has certain limitations. We have not considered inflation rate while estimating operating expenses in free cash flow process. The model has two facets, uses both environmental and accrual accounting information. Hence, it has not aimed to compare with any RIM, DDM or DCF methods. The NRR approach mainly fits for service entities like hospitals, hotels \& restaurants, spa, tours \& travels and educational institutions. Finally, this model could not match the requirements of businesses other than services. Future researchers with in this area may apply NRR 1.0. valuation model to validate in manufacturing business, conversely comparison of different valuation models and primary research on valuation practitioners. Further, model could be improved by altering any of the variables to be fit for valuation consultants.

\section{Endnotes}

Forecasting hurdle rate has computed by using various parameters, which compiled from believable sources.

\begin{tabular}{|c|c|c|}
\hline DNSGR & Domestic net sales growth rate in hospitality & 0.13 \\
\hline GHGR & Global hospitality growth rate & 0.06 \\
\hline \multirow{2}{*}{ MS } & Market share of select case & \multirow{2}{*}{$0.16,0.09$} \\
\hline & EIH and Leela & \\
\hline GRAT & Growth rate in arrival of tourists & 0.093 \\
\hline DDT & Domestic demand in tourism & 0.082 \\
\hline \multirow[t]{2}{*}{ PCMS } & Prime competitor market share (Taj group of hotels) & \multirow[t]{2}{*}{0.28} \\
\hline & log Whole sale price index (food articles) change & \\
\hline $\log$ WPI.GR & $\begin{array}{l}\{(2010 \text { index - average of 2005-2009 index }) / \text { average of 2005-2009 index }\} \times \\
100\end{array}$ & 1.4845 \\
\hline \multirow[t]{2}{*}{$\log \mathrm{Cm} . \mathrm{R}$} & log Commercial risk & \multirow[t]{2}{*}{$\log 3$} \\
\hline & log Exchange risk (Rupee vs. US dollar) & \\
\hline \multirow[t]{2}{*}{$\log$ EX.R } & $\{($ present rate -184 day average $) / 184$ day average $\} \times 100$ & \multirow[t]{2}{*}{0.45} \\
\hline & Present rate on Sept 30, 2010. & \\
\hline $\log$ PRST & log Political risk for special transactions & $\log 2$ \\
\hline $\log \mathrm{TR}$ & log Transfer risk & $\log 3$ \\
\hline FHR & Forecasting hurdle rate (\%) (EIH and Leela) & $5.30,4.92$ \\
\hline
\end{tabular}

Acknowledgements: The abridged version of this paper has been presented at International Finance Conference (FINCON-2011) organized by Management Development Institute, Gurgaon and University of Connecticut Business School, USA during Jan 07-08 and thanks to the participants for their valuable comments and feedback. We also thank Mr. Deepak Bhat, Information officer, Centre for Monitoring Indian Economy (CMIE) Private Limited, Mumbai and his intuitive suggestions on the manuscript is profoundly acknowledged. 


\section{References}

Antia, M., Lin, J.B. \& Pantzalis, C. (2007). Cultural distance and valuation of multinational corporations. Journal of Multinational Financial Management, 17(5), 365-383. http://dx.doi.org/10.1016/j.mulfin.2006.10.002

Bai, C., Liu, Q., Lu, J., Song, F.M. \& Zhang, J. (2004). Corporate governance and market valuation in China. Journal of Comparative Economics, 32(4), 599-616. http://dx.doi.org/10.1016/j.jce.2004.07.002

Bailey, P., Brown, P., Potter, M. \& Wells, P. (2008). A practical comparison of firm valuation models: cash flow, dividend and income. The Finsia Journal of Applied Finance, 2, 22-28. Available at: http://www.finsia.com/eventPDF/JASSA_Issue2_2008_ Pages_22-28.pdf, last accessed on Oct 28, 2010.

Becher, D.A. (2000). The valuation effects of bank mergers. Journal of Corporate Finance, 6(2), 189-214. http://dx.doi.org/10.1016/S0929-1199(00)00013-4

Bharadwaj, A. \& Shivdasani, A. (2003). Valuation effects of bank financing in acquisitions. Journal of Financial Economics, 67(1), 113-148. http://dx.doi.org/10.1016/S0304-405X(02)00233-7

Bryan, K. (2003). Handbook of financial modeling for business decisions. New Delhi: Crest Publishing.

Chaney, P.K. \& Lewis, C.M. (1995). Earnings Management and firm valuation under asymmetric information. Journal of Corporate Finance, 1(3-4), 319-345. http://dx.doi.org/10.1016/0929-1199(94)00008-I

Damodaran, A. (1996). Investment valuation - Tools and Techniques for determining the value of any asset. John Wiley \& sons Inc.

EIH Limited company profile. Available at: www.oberoihotels.com, last accessed on Oct 15, 2010.

Federation of Hotel and Restaurant Associations of India (FHRAI), available at: www.fhrai.com, last accessed on Oct 10, 2010.

Fernandez, P. (2002). Three residual income valuation methods and discounted cash flow valuation. www.ssrn.com/abstract=296945, last accessed on May 05, 2011.

Fernandez, P. (2003). How to value a seasonal company discounting cash flows. Available at: www.ssrn.com/abstract=406220, last accessed on May 05, 2011.

Fernandez, P. (2007a). Company valuation methods: The most common errors in valuations. Available at: www.ssrn.com/abstract=274973, last accessed on May 05, 2011.

Fernandez, P. (2007b). Valuing companies by cash flow discounting: ten methods and nine theories. Managerial $\quad$ Finance, 33(11), 853-876. http://dx.doi.org/10.1108/03074350710823827 
Grant Thornton - Dealtracker (2008). Providing business owners with M\&A market insight. New Delhi: Grant Thornton.

Hotel Leelaventure Limited company profile. Available at: www.theleela.com, last accessed on Oct 15, 2010.

Krishnamurthy, C. \& Viswanath, S.R. (2009). Advanced Corporate Finance. New Delhi: PHI Learning Private Ltd.

Kroszner, R.S. \& Strahan, P.E. (2000). Bankers on boards: monitoring, conflicts of interest, and lender liability. Journal of Financial Economics, 62(3), 415-452. http://dx.doi.org/10.1016/S0304-405X(01)00082-4

Lin, C. \& Su, D. (2008). Industrial diversification, partial privatization and firm valuation: Evidence from publicly listed firms in China. Journal of Corporate Finance, 14(4), 405-417. http://dx.doi.org/10.1016/j.jcorpfin.2008.05.001

Ma, Q., Whidbee, D.A. \& Zhang, A.W. (2011). Value, valuation, and the long-run performance of merged firms. Journal of Corporate Finance, 17(1), 1-17.

Michael, B. (2003). How to Figure Out Company Accounts. London: Texere Publishing Ltd.

Ministry of Tourism, Government of India. Available at: www.tourism.gov.in, last accessed on Sept 30, 2010.

Misund, B., Asche, F. \& Osmundsen, P. (2008). Industry upheaval and valuation: Empirical evidence from the international oil and gas industry. The International Journal of Accounting, 43(4), 398-424. http://dx.doi.org/10.1016/j.intacc.2008.09.007

Pandey, I.M. (2009). Financial Management, Ninth edition. New Delhi: Vikas Publishing House Pvt Ltd.

Plenborg, T. (2002). Firm valuation: comparing the residual income and discounted cash flow approaches. Scandinavian Journal of Management, 18(3), 303-318. http://dx.doi.org/10.1016/S0956-5221(01)00017-3

Ray, K.G. (2010). Mergers and Acquisitions - Strategy, Valuation and Integration. New Delhi: PHI Learning Private Ltd.

Ross, S.A., Westerfield, R.W. \& Jaffee, J. (2005). Corporate Finance, Seventh edition. New Delhi: Tata McGraw - Hill Publishing.

Velez-Pareja, I. \& Tham, J. (2010). Estimating cash flows for project appraisal and firm valuation. Available at: http://ssrn.com/abstract=1557845, last accessed on Oct 30, 2010.

Wilcox, H.D., Chang, K-C. \& Grover, V. (2001). Valuation of mergers and acquisitions in the telecommunications industry: a study on diversification and firm size. Information \& Management, 38(7), 459-471. http://dx.doi.org/10.1016/S0378-7206(00)00082-3

Yermack, D. (1996). Higher market valuation of companies with a small board of directors. Journal of Financial Economics, 40(2), 185-211. 
http://dx.doi.org/10.1016/0304-405X(95)00844-5

\section{Further Readings}

Bindal, H. (2010). Make The Most Out of India Growth Story. ET Investor's Guide -The Economic Times, 2 (Oct 18).

India Infoline data warehouse, available at: www.indiainfoline.com, last accessed on Sept 21, 2010.

Roy, D. (2010). Attrition hits Indian Hospitality. Available at: http://economictimes. indiatimes.com/features/financial-times/Attrition-hits-Indian-hospitality-industry /articleshow/6675470.cms, last accessed on Oct 10, 2010.

Peck, S. \& Temple, P. (2002). Mergers and Acquisitions - Critical Perspectives on Business and Management (Eds). Routledge - Taylor \& Francis group.

Ragozzino, R. (2006). Firm valuation effects of high-tech M\&A: A comparison of new ventures and established firms. Journal of High Technology Management Research, 17(1), 85-96. http://dx.doi.org/10.1016/j.hitech.2006.05.006

Tourism \& Hospitality, India Brand Equity Foundation, (2010), available at: http://www.ibef.org/artdispview.aspx?in=74\&art_id=26026\&catid=120\&page=1May, last accessed on Sept 30, 2010.

West, T.L. \& Jeffrey, J.D. (1999). Handbook of Business Valuation, Second edition. John Wiley \& sons Inc.

Appendix I: Financial Analysis of EIH Limited and Hotel Leelaventure Limited, 2006-2010

\begin{tabular}{|c|c|c|c|c|c|c|c|c|c|c|}
\hline & \multicolumn{5}{|c|}{ Hotel Oberoi (EIH Limited) } & \multicolumn{5}{|c|}{ Hotel Leelaventure Limited } \\
\hline & 2006 & 2007 & 2008 & 2009 & 2010 & 2006 & 2007 & 2008 & 2009 & 2010 \\
\hline Total borrowings/Net worth Ratio & 0.68 & 0.67 & 0.62 & 0.72 & 0.89 & 1.28 & 1.06 & 2.19 & 1.20 & 1.40 \\
\hline Net Profit Ratio (NP) & 24.96 & 21.34 & 19.33 & 18.07 & 6.95 & 22.36 & 32.07 & 27.69 & 30.72 & 9.12 \\
\hline Return on Net worth (RONW) & 18.06 & 17.07 & 16.64 & 12.02 & 4.04 & 8.87 & 14.01 & 15.97 & 7.13 & 2.00 \\
\hline Return on Capital Employed(ROCE) & 13.86 & 14.20 & 15.57 & 10.61 & 3.15 & 5.67 & 9.59 & 7.24 & 4.14 & 1.24 \\
\hline Return on Assets(ROA) & 8.73 & 8.66 & 8.60 & 5.94 & 1.86 & 3.54 & 6.04 & 4.54 & 2.94 & 0.77 \\
\hline Return on Fixed Assets(ROFA) & 13.83 & 13.25 & 12.33 & 8.60 & 2.63 & 4.73 & 7.38 & 5.66 & 3.32 & 0.84 \\
\hline Current Ratio(CR) & 1.40 & 1.15 & 1.06 & 1.20 & 1.32 & 3.81 & 1.93 & 3.11 & 1.53 & 1.44 \\
\hline Quick Ratio(QR) & 1.25 & 1.02 & 0.94 & 1.10 & 1.20 & 3.55 & 1.66 & 2.92 & 1.40 & 1.28 \\
\hline Debtors Turnover Ratio(DTR) & 5.17 & 6.11 & 5.76 & 3.87 & 3.25 & 1.64 & 2.18 & 1.78 & 1.15 & 1.45 \\
\hline Asset Turnover Ratio(ATR) & 0.35 & 0.41 & 0.44 & 0.33 & 0.27 & 0.16 & 0.19 & 0.16 & 0.10 & 0.08 \\
\hline Fixed Assets Turnover Ratio(FATR) & 0.55 & 0.62 & 0.64 & 0.48 & 0.38 & 0.21 & 0.23 & 0.20 & 0.11 & 0.09 \\
\hline
\end{tabular}

